\title{
Flavonoids isolated from the South African weed Chromolaena odorata (Asteraceae) have pharmacological activity against uropathogens
}

Aitebiremen G. Omokhua-Uyi ${ }^{1,2}$, Muna A. Abdalla ${ }^{1,3}$, Carmen M. Leonard ${ }^{4}$, Abimbola Aro ${ }^{1}$, Osariyekemwen O. Uyi ${ }^{5^{*}}$ D, Johannes Van Staden ${ }^{2}$ and Lyndy J. McGaw ${ }^{1}$

\begin{abstract}
Background: Urinary tract infections (UTIs) caused by opportunistic pathogens are among the leading health challenges globally. Most available treatment options are failing as a result of antibiotic resistance and adverse effects. Natural sources such as plants may serve as promising alternatives.

Methods: Compounds were isolated from the South African weed Chromolaena odorata through column chromatography. Purified compounds were tested for antimicrobial activity using the p-iodonitrotetrazolium chloride (INT) colorimetric method, against uropathogenic Escherichia coli, Staphylococcus aureus, Klebsiella pneumoniae, Aspergillus fumigatus and Cryptococcus neoformans. Anti-biofilm, anti-adhesion and metabolic inhibition activities were investigated against selected strains. Safety of the compounds was determined against Vero monkey kidney, C3A human liver and colon (Caco2) cells.

Results: Four compounds identified as pectolinaringenin (1), ( \pm )-4',5,7-trimethoxy flavanone (2), 5-hydroxy-3,7,4'trimethoxyflavone (3) and 3,5,7-trihydroxy-4'-methoxyflavone) (4) were isolated. Minimum inhibitory concentration (MIC) varied between 0.016 and $0.25 \mathrm{mg} / \mathrm{mL}$. Compounds 2 and 3 showed promising antimicrobial activity against E. coli, S. aureus, K. pneumoniae, A. fumigatus and C. neoformans with MIC between 0.016 and $0.125 \mathrm{mg} / \mathrm{mL}$, comparable to gentamicin, ciprofloxacin and amphotericin B used as positive controls. Compounds 2 and 3 showed good anti-biofilm and metabolic inhibition activities against E. coli and S. aureus but weak anti-adhesion activity against the organisms. Low toxicity with selectivity indexes between 1 and 12.625 were recorded with the compounds, indicating that the compounds were rather toxic to the microbial strains and not to the human and animal cells.

* Correspondence: osariyekemwen.uyi@uniben.edu

${ }^{5}$ Department of Animal and Environmental Biology, University of Benin, P.M.B, Benin City 1154, Nigeria

Full list of author information is available at the end of the article

(c) The Author(s). 2020 Open Access This article is licensed under a Creative Commons Attribution 4.0 International License, which permits use, sharing, adaptation, distribution and reproduction in any medium or format, as long as you give appropriate credit to the original author(s) and the source, provide a link to the Creative Commons licence, and indicate if changes were made. The images or other third party material in this article are included in the article's Creative Commons. licence, unless indicated otherwise in a credit line to the material. If material is not included in the article's Creative Commons licence and your intended use is not permitted by statutory regulation or exceeds the permitted use, you will need to obtain permission directly from the copyright holder. To view a copy of this licence, visit http://creativecommons.org/licenses/by/4.0/ The Creative Commons Public Domain Dedication waiver (http://creativecommons.org/publicdomain/zero/1.0/) applies to the data made available in this article, unless otherwise stated in a credit line to the data. 
(Continued from previous page)

Conclusion: Pharmacological activities displayed by compounds 2 and 3 isolated from C. odorata and low toxicity recorded credits it as a potential lead for the development of useful prophylactic treatments and anti-infective drugs against UTIs. Although known compounds, this is the first time these compounds have been isolated from the South African weed C. odorata and tested for antimicrobial, anti-biofilm, metabolic inhibition and anti-adhesion activities.

Keywords: South Africa, Compounds, Chromolaena odorata, Antimicrobial, Anti-biofilm, Metabolic activity, Antiadhesion, Toxicity

\section{Background}

The health challenges posed by infectious diseases caused by opportunistic pathogens globally cannot be overemphasized. Infectious diseases are one of the leading causes of death, especially among the immuno-compromised population [1-3]. Opportunistic pathogens have been reported as a major cause of urinary tract infections (UTIs) in both humans and animals [4]. These include pathogens such as Escherichia coli, Klebsiella pneumoniae, Pseudomonas aeruginosa, Staphylococcus aureus, Enterococcus faecalis, Candida albicans, Aspergillus fumigatus and Cryptococcus neoformans among others [5-11]. A plethora of antibiotics are used for the treatment of UTIs; however, the development of resistance to most of these antibiotics and adverse side effects have led to a continuous search for alternatives [12, 13].

Opportunistic pathogens contribute to over $80 \%$ of opportunistic infections in humans [14]. Biofilms are employed by most opportunistic pathogens as a mechanism of resisting antibiotics in humans [14]. The major factor that promotes biofilm formation is changes in the environment leading to the transition of bacteria from planktonic growth to biofilm formation. This causes changes in the expression of surface molecules, virulence factors, and metabolic status, enabling the bacteria to acquire properties that assist them to survive even in harsh conditions [15-17]. These pathogens can adhere to surfaces such as the lungs, tooth enamel, middle ear, heart valves, and intestinal wall and also to medical devices such as catheters in humans and animals [18]. Apart from the issue of resistance, availability and accessibility of these drugs especially to the rural poor in developing countries is also a barrier to the management of these infections. Hence, interest in the use of plants which are easily reached by the locals as sources of treatments, either as concoctions (herbal remedies) or isolated compounds, against opportunistic infections including UTIs has been growing over the years, as plants contain a wide range of bioactive compounds [19].

Chromolaena odorata (L.) King and Robinson, native to the Americas, is an herbaceous perennial flowering shrub belonging to the Asteraceae family [20]. Following its introduction into West Africa in 1937 and to South
Africa in 1947 [21-23], the plant has spread to different parts of the continent. Two biotypes are present in Africa, viz. the Asian/West African biotype (AWAB) originating from the Americas and the South African biotype (SAB) originating from Jamaica or Cuba [24-26]. Both biotypes are problematic in their invasive range as they impact negatively on natural vegetation, agriculture and livelihood, causing a decline in biodiversity due to their strong allelopathic properties and ability to survive in harsh conditions, and hence they are regarded as invasive weeds [22, 27, 28].

The AWAB is popularly known in traditional practice for the treatment of skin infections, wounds and inflammation [29-31]. The plant is used in different parts of its invasive range for the treatment of malaria, abdominal and cervical pain, urinary tract infections, gonorrhoea, ulcers, diarrhoea, coughs, colds and skin eruptions [27, 32-37]. A previous study comparing the antimicrobial activity of the two biotypes reported that the $\mathrm{SAB}$ contained the same medicinal properties as the AWAB that may be useful in combating antibacterial and antifungal infections $[38,39]$. Several bioactive compounds have been isolated from the AWAB including components of essential oils and flavonoids [37]. The isolation of pure compounds responsible for activities possessed by medicinal plants has become an important line of research as a lead or marker for the development of antimicrobial drugs [40]. According to Cos et al. [41], plant products, either as standardised extracts or isolated pure compounds, afford promising opportunities for the discovery of new drugs. This study was designed to isolate compounds from the weed plant $C$. odorata invasive in South Africa and to evaluate them for antimicrobial, anti-biofilm, anti-adhesion and metabolic inhibition activities against selected uropathogenic organisms, as leads for the development of possible treatment against UTIs.

\section{Methods}

\section{Collection of plant material}

The leaves of $C$. odorata were collected from Sappi Cannonbrae plantation, Umkomaas $\left(30^{\circ} 13^{\prime} \mathrm{S}, 30^{\circ} 46^{\prime} \mathrm{E}\right)$ (south coast of KwaZulu-Natal province), South Africa. 
The management of Sappi Cannonbrae plantation granted us permission to use their site for $C$. odorata research because the plant is an invasive alien plant and a category 1 weed (which must be removed from all properties) in South Africa [39]. A voucher specimen, Coll. No. 5 PRU 123727 Chromolaena odorata (L.) King and Robinson, was prepared and deposited at the H.G.W.J. Schweickerdt Herbarium, University of Pretoria South Africa, after identification by the herbarium curator Mrs. Elsa van Wyk. Leaves of plants collected were thoroughly cleaned and dried at room temperature in a drying room at the Department of Paraclinical Sciences, University of Pretoria following the guidelines of McGaw and Eloff [42]. The dried leaves were ground to powder using a grinder and stored in sealed glass jars to be used for further study.

\section{Chemicals, reagents and cell lines}

Ethanol, methanol, acetone, acetonitrile, Mueller Hinton broth (MHB), Mueller Hinton agar (MHA), Tryptone soy broth (TSB), Tryptone soy agar (TSA), Sabouraud dextrose broth (SDB), Sabouraud dextrose agar (SDA), Bovine serum albumin (BSA), Phosphate Buffer Saline (PBS), Triton-X 100, p-iodonitrotetrazolium chloride (INT), Thiazolyl Blue Tetrazolium Bromide (MTT), Amphotericin B, ciprofloxacin and Dimethyl sulphoxide (DMSO) were purchased from Sigma Aldrich, South Africa. Gentamicin was purchased from Virbac, New Zealand, Silica gel 60 from Merck, Germany, Minimal essential medium (MEM), Dulbecco's Modified Eagle's Medium (DMEM) and foetal calf serum (FCS) from Highveld Biological, South Africa. Cell lines C3A human hepatocyte (ATCC No. CRL-10741) and human colon (Caucasian colon adenocarcinoma (Caco2)) (ATCC HTB 37) were purchased from America Type Culture Collection, while Vero African green Monkey kidney cells was obtained from the collection of the Department of Veterinary Tropical Diseases, University of Pretoria.

\section{Bulk extraction of plant material}

To the powdered leaf material ( $150 \mathrm{~g}$ for methanol and $150 \mathrm{~g}$ for acetone), $1500 \mathrm{~mL}$ of each solvent were added and placed in the sonicator (EUmax UD200SH) for $1 \mathrm{~h}$. Ice was added to the sonicator to avoid overheating. The mixtures were filtered through Whatman No.1 filter paper using a Buchner funnel. The process was repeated twice and resultant filtrates according to solvent used were combined in a round bottomed flask and concentrated under reduced pressure using a Buchi Rotavapor R-200 (Switzerland) at temperatures between $50^{\circ} \mathrm{C}$ and $60^{\circ} \mathrm{C}$. The concentrated extracts were rinsed out of the round bottomed flasks, poured into weighed glass bottles, and placed under a stream of air to dry completely. Dried extracts were weighed with the methanol extract yielding $17.516 \mathrm{~g}$ and the acetone extract yielding 16.193 g. Both extracts were mixed together amounting to approximately $34 \mathrm{~g}$. The two solvent extracts (methanol and acetone) were combined owing to the presence of some similar phytoconstituents on developed thin layer chromatographic (TLC) plates under ultraviolet light and sprayed with vanillin reagent when viewed under the ultraviolet light and same retention factor (Rf) values obtained. Also, based on results obtained from preliminary antimicrobial activity screening in a previous study, methanol and acetone were chosen as solvents of choice for bulk extraction to ensure a proper target of active compounds from the plants.

\section{Isolation of bioactive compounds}

Following the method of Suffness and Douros [43] adapted by Eloff [44] with little modification, the combined extract was partitioned between water, hexane, chloroform, ethyl acetate and butanol in this order. Following biological assays against micro-organisms of interest and thin-layer chromatography guided procedures, the hexane (total yield of $11.305 \mathrm{~g}$ ) and chloroform (total yield of $4.895 \mathrm{~g}$ ) fractions showing similar antimicrobial results were combined to obtain a crude extract of $16.2 \mathrm{~g}$. This was fractionated through column chromatography using silica gel 60 mixed with hexane to form a slurry in a glass column $10 \mathrm{~cm}$ in diameter and $50 \mathrm{~cm}$ in length. The mixture was eluted with hexane (hex) followed by stepwise addition of ethyl acetate (EtOAc) (gradient 0 to $100 \%$ ) followed by ethyl acetate: methanol $(\mathrm{MeOH})$ gradient (till $100 \% \mathrm{MeOH})$. For each eluent mixture $1000 \mathrm{~mL}$ were used and further decreased to $500 \mathrm{~mL}$. Fractions were collected in round bottomed flasks of $250 \mathrm{~mL}$ and concentrated using a rotary evaporator. A total of 76 fractions were collected. Based on TLC monitoring through solvent mobile phases of varying polarity which included benzene/ethanol/ammonium hydroxide (BEA 90:10:1, non-polar/ basic); chloroform/ethyl acetate/ formic acid (CEF 5:4:1, intermediate polarity/acidic) and ethyl acetate/methanol/ water (EMW 40:5:4.5, polar/neutral), fractions showing similar chromatograms were first combined to obtain 21 fractions. Following a second TLC observation, these fractions were further combined to finally obtain a total of six main fractions: F1 [hex/EtOAc (100:0 and 80:20), $3.7 \mathrm{~g}$ ], F2 [hex/EtOAc (70:30 and 50:50), $2.04 \mathrm{~g}$ ], F3 [hex/ EtOAc (50:50, 30:70 and 0:100), 1.94 g], F4 [EtOAc/ $\mathrm{MeOH}$ (90:10 and 70:30), $2.51 \mathrm{~g}$ ], F5 [EtOAc/MeOH (70: 30 and 50:50), $2.1 \mathrm{~g}$ ], F6 [EtOAc/MeOH (30:70 and 0: $100), 2.44 \mathrm{~g}]$. Following biological activity investigation, fraction 2 [F2 [hex/EtOAc (70:30 and 50:50), 2.04 g]], and fraction 3 [F3 [hex/EtOAc (50:50, 30:70 and 0:100), $1.94 \mathrm{~g}]$ ], were chosen for further purification. Fraction 2 was subjected to column chromatography using a 
Sephadex LH-20 column with a diameter of $2 \mathrm{~cm}$ and length of $50 \mathrm{~cm}$ eluted isocratically with methanol and this yielded compound 1 ( $2.8 \mathrm{mg}$ retention factor $=0.76$ ). Fraction 3 was subjected to the same process and further to preparative thin layer chromatography (PTLC) to yield compounds $2(67.2 \mathrm{mg}$, retention factor $=0.89), 3$ $(67 \mathrm{mg}$, retention factor $=0.91)$ and $4(8.5 \mathrm{mg}$, retention factor $=0.85$ ).

\section{Structural elucidation of isolated compounds}

The structures of compounds 1, 2, 3, 4 were elucidated using Mass Spectrometry and Nuclear Magnetic Resonance (NMR) spectroscopic techniques. The various compounds were identified through 1-dimensional NMR $\left({ }^{1} \mathrm{H}\right.$ and ${ }^{13} \mathrm{C}$ ) and 2-dimensional NMR. Data were acquired on a $400 \mathrm{MHz}$ NMR model (Bruker Avance III 400 $\mathrm{MHz}$ ). Where the quantity of compound was too low a $500 \mathrm{MHz}$ NMR instrument was used. The various compounds were prepared with Ultra Performance Liquid Chromatography (UPLC) grade acetonitrile and water and the mass of each compound was determined with a HR-ESI-MS (Waters Acquity) UPLC system hyphenated to a quadrupole-time-of-flight (QTOF). Chemical shifts were reported with reference to respective deuterated solvent peaks. The structures of compounds isolated were confirmed by comparing their NMR data with published literature.

\section{Antimicrobial screening \\ Microbial cultures and maintenance}

The cultures used were Escherichia coli (American Type Culture Collection, ATCC 25922) labelled as 1, E. coli isolates (B1989/17 and B1962/17) labelled as 2 and 3 from equine urine, collected from the Department of Veterinary Tropical Diseases, Faculty of Veterinary Science, University of Pretoria, South Africa, Klebsiella pneumoniae isolate from commercial chicken eggs [45], Enterococcus faecalis (ATCC 29212), Pseudomonas aeruginosa (ATCC 27853), Staphylococcus aureus (ATCC 29213), Candida albicans from a Gouldian finch, Aspergillus fumigatus from a chicken and Cryptococcus neoformans from a cheetah [45]. These microbial strains were maintained on MHA or SDA for bacteria and fungi respectively, while the isolates were maintained on blood agar.

\section{Determination of minimum inhibitory concentration (MIC)}

Ten $\mathrm{mg} / \mathrm{mL}$ of each fraction and $1 \mathrm{mg} / \mathrm{mL}$ of isolated compounds were prepared in 10\% DMSO and tested against S. aureus, E. coli, K. pneumoniae, E. faecalis, $P$. aeruginosa, C. albicans, C. neoformans and A. fumigatus. Cultures were prepared by inoculating each microbial strain from prepared agar plates into sterilized MHB for bacterial and SDB for fungi in sterile McCartney bottles respectively. The inoculums were placed in an orbital shaker incubator. Bacterial strains were incubated at $37^{\circ} \mathrm{C}$ for $18 \mathrm{~h}$. Each bacterial culture was diluted in fresh MHB and the absorbance was measured at a wavelength of $560 \mathrm{~nm}$ using a microplate reader (Epoch Biotek). The readings were compared to a McFarland standard No. 1 correlating to approximately $3 \times 10^{8} \mathrm{cfu} / \mathrm{mL}$ ). For fungi strains, cultures were incubated at $30^{\circ} \mathrm{C}$ for $24 \mathrm{~h}(C$. albicans), $72 \mathrm{~h}$ (C. neoformans) and $120 \mathrm{~h}$ (A. fumigatus) respectively. The resultant cells and spores were washed with sterile normal saline and absorbance was measured at a wavelength of $560 \mathrm{~nm}$ and turbidity was adjusted to a McFarland standard 1.This was further diluted in a 1 : 10 ratio in SDB to a turbidity of $5 \times 10^{5} \mathrm{cfu} / \mathrm{mL}$. These diluted cultures (bacterial and fungi) were used for the screening following the serial microdilution method of Eloff [46].

\section{Biofilm inhibition assay Inhibition of planktonic and pre-formed biofilms}

A single colony of E. coli (ATCC 25922) and S. aureus (ATCC 29213), strains were each inoculated into TSB and incubated for $24 \mathrm{~h}$. The biofilm inhibition assay was carried out by adopting the method described by Sandasi et al. [47]. Two stages; planktonic, T0 and biofilm formation, T24 were investigated against the $24 \mathrm{~h}$ prepared bacterial cultures. One hundred microliters of each standardised bacterial culture $\left(\mathrm{OD}_{590} 1 \times 10^{6} \mathrm{cfu} / \mathrm{mL}\right)$ was aliquoted into wells of a sterile flat bottomed 96 -well microplate. Plates prepared for $24 \mathrm{~h}$ biofilm formation were immediately sealed with an adhesive sealer, placed in the incubator and incubated for $24 \mathrm{~h}$ at $37^{\circ} \mathrm{C}$. From the different concentrations of the compounds prepared in their MICs multiplied by 2 (to make final concentrations in the wells to be $0.016,0.031,0.063$ and $0.125 \mathrm{mg} / \mathrm{mL}$ ) and a cut-off concentration of $1 \mathrm{mg} / \mathrm{mL}, 100 \mu \mathrm{L}$ was added to the wells. Similarly, positive controls (ciprofloxacin and gentamicin with final concentration of 0.01 and $0.032 \mathrm{mg} / \mathrm{mL}$ ) were included. To the plates prepared for $0 \mathrm{~h}$, the samples were added immediately. Wells containing cultures only, as well as acetone and sterile distilled water used to prepare the samples were included as controls. All plates after the addition of samples were sealed and incubated for $24 \mathrm{~h}$ to enable the samples to react with the biofilms.

\section{Crystal violet staining assay}

The incubated plates were washed with sterile distilled water three to four times after incubation to remove the unattached cells and were placed in the oven at $60^{\circ} \mathrm{C}$ for $45 \mathrm{~min}$. To all wells, $100 \mu \mathrm{L}$ of $1 \%$ crystal violet dissolved in distilled water was added and plates were incubated for $15 \mathrm{~min}$ at room temperature after which the plates were washed again with sterile distilled water to remove 
unabsorbed stain. One hundred and twenty-five microliters of $100 \%$ ethanol was added to destain the wells. From the wells, $100 \mu \mathrm{L}$ of the destaining solution was transferred to a new plate and semi-quantitative assessment of biofilm formation was done by measuring absorbance at $590 \mathrm{~nm}$ using SoftMax Pro 6 software on a microplate reader (SpectraMax M2). The mean absorbance of the samples was determined, and percentage inhibition was obtained using the equation below:

$$
\text { percentage inhibiton }=\frac{(\text { mean of culture control }- \text { mean of sample })}{\text { mean of culture control }} \times 100
$$

\section{Metabolic activity inhibition}

The ability of the isolated compounds to inhibit the bacterial metabolic activity was tested against E. coli and $S$. aureus following the method used by Ramage and Lopez-Ribot [48] with slight modification. The organisms were inoculated in a 96-well microplate following the same biofilm assay procedure described above. The final concentration of each compound in the wells was $0.016 \mathrm{mg} / \mathrm{mL}, 0.031 \mathrm{mg} / \mathrm{mL}, 0.063 \mathrm{mg} / \mathrm{mL}, 0.125 \mathrm{mg} / \mathrm{mL}$ and $1 \mathrm{mg} / \mathrm{mL}$ respectively. After $24 \mathrm{~h}$ of incubation with samples, the plates were washed three times with sterile distilled water and $50 \mu \mathrm{L}$ of $1 \mathrm{mg} / \mathrm{mL}$ INT was added to each well and further incubated in the dark for $2 \mathrm{~h}$. After incubation, absorbance was read at $490 \mathrm{~nm}$ using a microplate reader and the percentages of reduction of bacterial metabolic activity in the presence of different concentrations of compounds were calculated using the formula:

$$
\text { percentage inhibiton }=\frac{(\text { mean of culture control }- \text { mean of sample })}{\text { mean of culture control }} \times 100
$$

\section{Cell adhesion to polystyrene surface}

Anti-adhesion activity of isolated compounds was determined using the method of Namasivayam and Vivek [49] with slight modification. To a sterile 96-well flatbottomed polystyrene microtititre plate, $150 \mu \mathrm{L}$ of freshly prepared $1 \%$ lyophilized powdered globular protein BSA, dissolved in water was added to all wells except for the wells allocated for media only. The plates were incubated for $30 \mathrm{~min}$ at $30^{\circ} \mathrm{C}$. Following incubation the wells were washed three times with PBS. To the wells, $50 \mu \mathrm{L}$ of bacterial cultures equivalent to $1 \times 10^{6}$ $\mathrm{cfu} / \mathrm{mL}$ read at $590 \mathrm{~nm}$, prepared from overnight cultures were added. This was followed by the addition of isolated compounds $1 \mathrm{mg} / \mathrm{mL}$, ciprofloxacin $0.01 \mathrm{mg} / \mathrm{mL}$ and gentamicin $0.032 \mathrm{mg} / \mathrm{mL}$ as final concentrations in the wells repectively. The seeded microtitre plates were incubated for $24 \mathrm{~h}$ at $37^{\circ} \mathrm{C}$. Non-adhered cells were washed five times with $\mathrm{PBS}$ at room temperature.
Adhered cells were stained by the addition of $50 \mu \mathrm{L}$ of $0.1 \%$ crystal violet and further incubation for a further $30 \mathrm{~min}$ at room temperature. Afterwards, wells were washed with sterile distilled water to remove excess stain followed by the addition of $10 \mu \mathrm{L}$ of absolute ethanol to fix the adhered cells. Finally, $50 \mu \mathrm{L}$ of $0.2 \%$ Triton $\mathrm{X}$ was added to the wells to lyse the cells and the absorbance was read at $570 \mathrm{~nm}$ using a microplate reader. Percentage adherence inhibition was calculated using the formula above.

\section{Cytotoxicity assay}

Different concentrations of the compounds ranging from 0.003 to $0.2 \mathrm{mg} / \mathrm{mL}$ were tested for cytotoxicity against three cell lines; Vero monkey kidney, C3A and Caco2. Vero cells were grown and maintained in MEM, supplemented with $0.1 \%$ gentamicin and $5 \%$ foetal calf serum, while Caco2 and C3A cells were grown and maintained in DMEM supplemented with $10 \%$ foetal calf serum, $1 \%$ non-essential amino acids and $1 \%$ penicillinstreptomycin. All cells were incubated in a $5 \% \mathrm{CO}_{2}$ incubator at $37^{\circ} \mathrm{C}$. Doxorubicin chloride was used as positive control while $10 \%$ DMSO used in dissolving the test samples was used as the negative control. The 3-(4,5-dimethylthiazol)-2,5-diphenyl tetrazolium bromide (MTT) assay described by Mosmann [50] with modification by McGaw et al. [51] was used to determine the cytotoxicity of the test samples. The lethal concentration $\left(\mathrm{LC}_{50}\right)$ value was calculated as the concentration of tested sample resulting in a $50 \%$ reduction of absorbance compared to untreated cells. Selectivity index (SI) values were calculated against the MIC using the formula:

$$
\mathrm{SI}=\mathrm{LC}_{50} / \mathrm{MIC} \text {. }
$$

\section{Statistical}

Microsoft Excel 2016 was used to analyse the data obtained from the different assays.

\section{Results \\ Structural elucidation and identification of isolated compounds}

The structures of isolated compounds were determined after analysing their various NMR spectra and comparison with established literature in the Dictionary of Natural Products and the Chemical Abstracts Services (Scifinder) [52-56] (Fig. 1).

Compound 1 was isolated as a whitish amorphous powder giving a strong UV absorbing band on TLC at $254 \mathrm{~nm}$ turning light yellow with vanillin/sulphuric reagent. The retention factor was 0.92 in CEF. The ESIMS delivered a pseudomolecular ion peak at $315.0888[\mathrm{M}+$ $\mathrm{H}]^{+}$and $313.0741[\mathrm{M}-\mathrm{H}]^{-}$which gave the molecular weight of 314 and the molecular formula $\mathrm{C}_{17} \mathrm{H}_{14} \mathrm{O}_{6}$ by HRESIMS. The ${ }^{1} \mathrm{H}$ NMR showed four aromatic proton 
<smiles>COc1ccc(-c2cc(=O)c3c(O)c(OC)c(O)cc3o2)cc1</smiles>

Pectolinaringenin (1)<smiles>COc1ccc(-c2oc3cc(OC)cc(O)c3c(=O)c2OC)cc1</smiles>

3,7,4'-Tri-O-methylkaempferol (3)<smiles>COc1ccc(C2CC(=O)c3c(OC)cc(OC)cc3O2)cc1</smiles>

$( \pm)-4 ', 5,7-T r i m e t h o x y$ flavanone (2)<smiles>COc1ccc(-c2oc3cc(O)cc(O)c3c(=O)c2O)cc1</smiles>

4'-Methoxykaempferol (3,5,7-trihydroxy4'-methoxyflavone) (4)

Fig. 1 Structures of isolated compounds from South African biotype Chromolaena odorata

signals: each two ortho-coupled protons of a $p$-disubstituted benzene appeared at $\delta 8.05\left(\mathrm{~d},{ }^{3} J=8.6, \mathrm{H}-2^{\prime}, 6^{\prime}\right)$ and $7.12\left(\mathrm{~d},{ }^{3} J=8.6, \mathrm{H}-3^{\prime}, 5^{\prime}\right)$ in addition to signals of protons in another rings at $\delta 6.89(\mathrm{H}-3, \mathrm{~s})$ and at $\delta 6.62$ $(\mathrm{H}-8, \mathrm{~s})$. Two methoxy protons appeared at $\delta 3.76(\mathrm{~s}, 6-$ $\left.\mathrm{OCH}_{3}\right)$ and $\delta 3.87\left(\mathrm{~s}, 4^{\prime}-\mathrm{OCH}_{3}\right)$. The ${ }^{13} \mathrm{C}$ NMR spectrum revealed 15 carbon signals, nine quaternary carbons at $\delta 182.6$ (C-4), 163.7 (C-2), $153.5(\mathrm{C}-5), 131.9$ (C-6), 158.1 (C-7), 152.7 (C-9), 104.6 (C-10),123.2 (C$\left.1^{\prime}\right), 162.7\left(\mathrm{C}-4^{\prime}\right)$, and four aromatic carbon signals at $\delta$ $103.6(\mathrm{CH}-3), 94.8(\mathrm{CH}-8), 128.8\left(\mathrm{CH}-2^{\prime}\right.$, and $\left.\mathrm{CH}-6^{\prime}\right)$, $115.0\left(\mathrm{CH}-3^{\prime}\right.$, and $\left.\mathrm{CH}-5^{\prime}\right)$, in addition to two methoxy carbons at $\delta 60.4\left(\mathrm{C}-6 \mathrm{OCH}_{3}\right)$ and $56.1\left(\mathrm{C}-4 \mathrm{OCH}_{3}\right)$. Additionally, further COSY and $\mathrm{HMBC}$ correlations identified the flavonoid structure as pectolinaringenin ( 5 , 7-dihydroxy- 4',6-dimethoxy-flavone) (1) (Fig. 1), by comparing the spectroscopic information with literature data [55].

Compound 2 was isolated as a yellowish-green amorphous powder. On TLC it showed a characteristic colour reaction of a flavonoid compound and retention factor in CEF was 0.91. The mass spectrum showed the pseudomolecular peak at $\mathrm{m} / \mathrm{z} 315.1226[\mathrm{M}+\mathrm{H}]^{+}$, consistent with the molecular formula, $\mathrm{C}_{18} \mathrm{H}_{18} \mathrm{O}_{5}$. The ${ }^{1} \mathrm{H}$ NMR revealed a typical flavanone pattern, with protons at positions $\mathrm{C}-2$ and $\mathrm{C}-3$, appeared at $\delta 2.96(1 \mathrm{H}$, dd, $J=2.5,16.5 \mathrm{~Hz}, \mathrm{H}-3 \alpha), 2.68(1 \mathrm{H} \mathrm{dd}, J=2.5,16.5 \mathrm{~Hz}, \mathrm{H}-$ $3 \beta)$, and $5.26\left(1 \mathrm{H}, \mathrm{d},{ }^{3} J=12.6 \mathrm{~Hz}, \mathrm{H}-2\right)$. From the ${ }^{1} \mathrm{H}$ NMR spectroscopic data, three methoxy protons appeared at $\delta \mathrm{H} 3.74\left(3 \mathrm{H}, \mathrm{s}, \mathrm{OMe}-4^{\prime}\right)$ and $3.80(3 \mathrm{H}, \mathrm{s}$, OMe-5) and $3.73(3 \mathrm{H}, \mathrm{s}, \mathrm{OMe}-7)$ in addition to four aromatic proton signals at $\delta 6.0(\mathrm{~s}, \mathrm{CH}-6), 6.06(\mathrm{~s}, \mathrm{CH}-$ 8), $7.29\left(\mathrm{~d},{ }^{3} J=8.2, \mathrm{C}-2^{\prime}\right.$, and $\left.\mathrm{C}-6^{\prime}\right)$, and $6.86\left(\mathrm{~d},{ }^{3} J=8.2\right.$, $\mathrm{C}-3^{\prime}$, and $\left.\mathrm{C}-5^{\prime}\right) .{ }^{13} \mathrm{CNMR}$ revealed seven quaternary carbon signals at $\delta 189.4$ (C-4), $162.3(\mathrm{C}-5), 165.8$ (C-7), 164.9 (C-9), 105.3 (C-10), $123.3\left(\mathrm{C}-1^{\prime}\right)$, and 160.1 (C-4'), in addition to four aromatic carbon signals at $\delta 93.2$ (CH-6), $93.6(\mathrm{CH}-8), 127.8\left(\mathrm{CH}-2^{\prime}\right.$, and $\left.\mathrm{CH}-6^{\prime}\right)$, and $114.2\left(\mathrm{CH}-3^{\prime}\right.$, and $\left.\mathrm{C}-5^{\prime}\right)$. Moreover, three methoxy carbon signals appeared at $\delta 55.9$ (C-4'OMe), 56.1 (C$5 \mathrm{OMe})$ and $55.6(\mathrm{C}-7 \mathrm{OMe})$ in addition to oxygenated methine at $\delta 78.9(\mathrm{CH}-2)$ and a methylene carbon signal at $45.3\left(\mathrm{CH}_{2}-3\right)$. Further COSY and HMBC correlations and a search in Chemical Abstracts Services (Scifinder) confirmed the structure as $( \pm)-4{ }^{\prime}, 5,7$-trimethoxy flavanone (Fig. 1).

Compound 3 was isolated as yellow crystals showing a strong UV absorbing band on TLC at $254 \mathrm{~nm}$ and turned to brown with vanillin/sulphuric acid reagent and retention factor was 0.852 . The ESIMS afforded a pseudomolecular ion peak at $329[\mathrm{M}+\mathrm{H}]^{+}$, which gave the molecular weight 328 and the molecular formula $\mathrm{C}_{18} \mathrm{H}_{16} \mathrm{O}_{6}$ by HRESIMS. Compound 3 was closely related to compound 4 as the ${ }^{1} \mathrm{HNMR}$ spectrum showed a typical flavonol pattern. For instance, a methoxy signal detected at $\delta 3.75(3 \mathrm{H}, \mathrm{s}, \mathrm{OMe}-3)$ in addition to two methoxy proton signals at $\delta 3.77\left(3 \mathrm{H}, \mathrm{s}, \mathrm{OMe}-4{ }^{\prime}\right)$ and $3.80(3 \mathrm{H}, \mathrm{s}, \mathrm{OMe})$. Moreover, two aromatic proton signals appeared at $\delta 6.45\left(\mathrm{~d},{ }^{3} J=2.1, \mathrm{CH}-6\right)$ and 6.49 (d, $\left.{ }^{3} J=2.1, \mathrm{CH}-8\right)$ in addition to two aromatic proton signals of a $p$-disubstituted benzene observed at $\delta 7.97(\mathrm{~d}$, $\left.{ }^{3} J=8.9, \mathrm{H}-2^{\prime}, 6^{\prime}\right)$ and $6.90\left(\mathrm{~d},{ }^{3} J=8.9, \mathrm{H}-3^{\prime}, 5^{\prime}\right) .{ }^{13} \mathrm{C}$ 
NMR spectrum afforded nine quaternary carbon signals at $\delta 156.9$ (C-2), 138.3 (C-3), 182.9 (C-4), 158.9 (C-5), 164.3 (C-7), 158.3 (C-9), 105.9 (C-10),123.0 (C-1'), 162.2 $\left(\mathrm{C}-4^{\prime}\right)$, four aromatic carbon signals at $\delta 93.5(\mathrm{CH}-6)$, 91.1 (CH-8), $130.2\left(\mathrm{CH}-2^{\prime}\right.$, and $\left.\mathrm{CH}-6^{\prime}\right)$, and $114.6(\mathrm{CH}-$

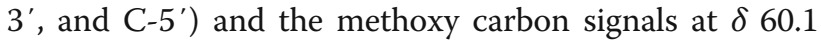
(C-4' $\mathrm{OMe}), 55.5$ (C-3OMe) and 55.9 (C-7OMe). COSY as well as $\mathrm{HMBC}$ correlationsidentified compound 3 as 3,7,4' 'tri-O-methylkaempferol (5-hydroxy-3,7,4' -trimethoxyflavone) (Fig. 1).

Compound 4 was isolated as a yellow amorphous powder, which gave a strong UV absorbing band on TLC at $254 \mathrm{~nm}$ and turned to yellowish-brown with vanillin/ sulphuric acid reagent. The retention factor when eluted with CEF was 0.89 . The ESIMS afforded a pseudomolecular ion peak at $\mathrm{m} / \mathrm{z} 301.0710[\mathrm{M}+\mathrm{H}]^{+}$, which gave the molecular weight 300 and the molecular formula $\mathrm{C}_{16} \mathrm{H}_{12} \mathrm{O}_{6}$ by HRESI MS. The ${ }^{1} \mathrm{H}$ NMR spectrum showed the typical pattern of a flavonoid: four aromatic proton signals were observed at $\delta 8.10\left(\mathrm{H}-2^{\prime}, 6^{\prime}\right), 6.97$ $\left(\mathrm{H}-3^{\prime}, 5^{\prime}\right), 6.39(\mathrm{H}-8)$ and $6.23(\mathrm{H}-6)$. Additionally, one methoxy signal appeared at $\delta 3.81\left(4^{\prime}-\mathrm{OCH}_{3}\right)$. The ${ }^{13} \mathrm{C}$ NMR spectrum revealed nine quaternary carbons $(\mathrm{Cq})$ at $\delta 181.6(\mathrm{C}-4), 161.8(\mathrm{C}-7), 161.2\left(\mathrm{C}-4^{\prime}\right), 161.1(\mathrm{C}-5)$, 157.6 (C-9), 146.0 (C-2), 137.7 (C-3), $123.3\left(\mathrm{C}-1^{\prime}\right)$ and 104.4 (C-10), in addition to four aromatic methine carbon signals at $129.3\left(\mathrm{CH}-2^{\prime}, 6^{\prime}\right), 114.2\left(\mathrm{CH}-3^{\prime}, 5^{\prime}\right), 98.8$ $(\mathrm{CH}-6)$ and $94.2(\mathrm{CH}-8)$ and a methoxy singlet at 55.9 $\left(4{ }^{\prime}-\mathrm{OCH}_{3}\right)$. 1D and 2D NMR data obtained for compound 4 showed typical signals for flavonol especially the 3-hydroxyflavone at $\delta 137.7(\mathrm{C}-3)$ as well as correlations confirming the flavonol skeleton. This compound was identified as 4'-methoxykaempferol (3,5,7-trihydroxy-4'-methoxyflavone). A literature search in the
Dictionary of Natural Products and the Chemical Abstracts Services (Scifinder) afforded the compound 4' methoxykaempferol, of which the spectral data was comparable to literature (as described in Mabry \& Harborne [52] (Fig. 1).

\section{Antimicrobial activity of fractions and isolated compounds}

Fractions and subfractions subjected to antimicrobial screening showed varying MIC values (from 0.08 to 2.5 $\mathrm{mg} / \mathrm{mL}$ ) (Tables 1 and 2). The hexane and chloroform fractions had the best activity against most of the strains tested with MICs of 0.08 and $0.16 \mathrm{mg} / \mathrm{mL}$. The antimicrobial activities of isolated flavonoid compounds are presented in Table 3. Compounds 2 and 3 inhibited all bacterial strains tested while compound 1 inhibited only $S$. aureus, $K$. pneumoniae and E. coli ATTC strain and the Compound 4 only $S$. aureus and E. coli ATCC strain. Compound 2 exhibited very good antibacterial activity against $E$. coli ATCC and isolates and $S$. aureus (MIC = $0.031 \mathrm{mg} / \mathrm{mL}$ ). Activity against $S$. aureus was better than that of the positive control ciprofloxacin, a very promising result. The average mean of the compound was $0.05 \pm 0.04$, almost comparable to that of gentamicin which had average MIC of $0.06 \pm 0.11$. Antibacterial activity exhibited by compound 3 ( $\mathrm{MIC}=0.016 \mathrm{mg} / \mathrm{mL}$ ) against $S$. aureus was better than that of ciprofloxacin with $\mathrm{MIC}=0.063 \mathrm{mg} / \mathrm{mL}$. Amongst all isolated compounds tested against the two fungal isolates, very good antifungal activity was displayed by Compound 2 with MIC $=0.016 \mathrm{mg} / \mathrm{mL}$ against $C$. neoformans and A. fumigatus at $48 \mathrm{~h}$, and the compound had the same average MIC value of $0.07 \pm 0.06$ as amphotericin B. Compound 3 showed MIC $=0.031 \mathrm{mg} / \mathrm{mL}$ only against $A$. fumigatus

Table 1 Minimum inhibitory concentration of fractions against selected microbial strains in mg/mL

\begin{tabular}{llllllllll}
\hline Organism & Time $(\mathrm{h})$ & Hexane & Chloroform & Butanol & ETAC & Water & Gent & Cipro & Amp B \\
\hline E. coli $(1)$ & - & $\mathbf{0 . 0 8 ^ { * }}$ & $\mathbf{0 . 1 6}$ & 0.63 & 1.25 & 0.63 & $\mathbf{0 . 0 2}$ & $\mathbf{0 . 0 0 2}$ & NA \\
K. pneumoniae & - & $\mathbf{0 . 1 6}$ & $\mathbf{0 . 1 6}$ & 0.63 & 1.25 & 0.63 & 0.500 & 0.050 & NA \\
E. faecalis & - & 0.63 & $\mathbf{0 . 1 6}$ & 0.63 & $>2.5$ & 0.63 & 0.500 & ND & NA \\
P. aeruginosa & - & 0.63 & 0.31 & 0.63 & 1.25 & 0.63 & $\mathbf{0 . 0 0 8}$ & ND & NA \\
S. aureus & - & $\mathbf{0 . 1 6}$ & $\mathbf{0 . 1 6}$ & 0.63 & 1.25 & $\mathbf{0 . 1 6}$ & $\mathbf{0 . 0 0 8}$ & 0.063 & NA \\
C. albicans & 24 & $\mathbf{0 . 0 8 ^ { * }}$ & 0.63 & 0.63 & 1.25 & 0.63 & $\mathbf{N A}$ & $\mathbf{N A}$ & $\mathbf{0 . 0 3 1}$ \\
& 48 & 0.31 & 2.5 & $>2.5$ & $>2.5$ & $>2.5$ & NA & NA & 0.063 \\
A. fumigatus & 48 & 0.31 & 2.5 & 1.25 & $>2.5$ & 1.25 & NA & NA & $\mathbf{0 . 0 3 1}$ \\
& 72 & 0.31 & 2.5 & $>2.5$ & $>2.5$ & $>2.5$ & NA & NA & 0.063 \\
& 120 & $>2.5$ & $>2.5$ & $>2.5$ & $>2.5$ & $>2.5$ & NA & NA & 0.125 \\
C. neoformans & 48 & 0.63 & 2.5 & 1.25 & 2.5 & 2.5 & NA & NA & $\mathbf{0 . 0 0 8}$ \\
& 72 & 0.63 & 2.5 & 1.25 & $>2.5$ & $>2.5$ & NA & NA & 0.125 \\
& 120 & $>2.5$ & $>2.5$ & $>2.5$ & $>2.5$ & $>2.5$ & NA & NA & 0.125 \\
\hline
\end{tabular}

ND not detected, NA not available, ETAC ethyl acetate, Gent gentamicin, Cipro ciprofloxacin, Amp B amphotericin B 
Table 2 Minimum inhibitory concentrations of combined fractions obtained from silica gel column against most susceptible strains in $\mathrm{mg} / \mathrm{mL}$

\begin{tabular}{lllllllll}
\hline Organism & \multirow{2}{*}{ Time (h) } & \multicolumn{2}{l}{ Sub-Fraction } & & & \\
\cline { 3 - 5 } & & & F1 & F2 & F3 & F4 & F5 & F6 \\
\hline S. aureus & - & $>2.5$ & $\mathbf{0 . 0 8 *}$ & $\mathbf{0 . 1 6}$ & $\mathbf{0 . 1 6}$ & 0.3 & 0.31 \\
K. pneumoniae & - & 1.25 & 0.3 & $\mathbf{0 . 1 6}$ & 0.63 & 0.313 & $\mathbf{0 . 1 6}$ \\
E. coli (1) & - & 0.63 & $\mathbf{0 . 1 6}$ & $\mathbf{0 . 1 6}$ & 0.63 & 0.63 & 0.63 \\
E. faecalis & - & 1.25 & 0.31 & 0.31 & 2.5 & 2.5 & 0.63 \\
C. albicans & 48 & 2.5 & $>2.5$ & 2.5 & 2.5 & 2.5 & 2.5 \\
& 72 & $>2.5$ & $>2.5$ & $>2.5$ & $>2.5$ & $>2.5$ & $>2.5$ \\
A. fumigatus & 48 & 1.25 & $\mathbf{0 . 1 6}$ & $\mathbf{0 . 0 8 *}$ & 0.63 & 1.25 & 0.31 \\
& 72 & $>2.5$ & 0.63 & 0.63 & $>2.5$ & $>2.5$ & $>2.5$ \\
& 120 & $>2.5$ & $>2.5$ & $>2.5$ & $>2.5$ & $>2.5$ & $>2.5$ \\
& 48 & $>2.5$ & 0.31 & 0.31 & 0.31 & $\mathbf{0 . 1 6}$ & 0.31 \\
C. neoformans & 48 & $>2.5$ & 0.63 & 1.25 & 2.5 & 2.5 & $>2.5$ \\
& 72 & &
\end{tabular}

F1 fraction 1, F2 fraction 2, F3 fraction 3, F4 fraction 4, F5 fraction 5, F6 fraction 6. Values with bold indicate promising antimicrobial activity while value in asterisk indicate best activity

at $48 \mathrm{~h}$, comparable to amphotericin B used as the positive control.

\section{Biofilm inhibition activity}

Results obtained with the isolated flavonoids at the planktonic and biofilm formation stages against $E$. coli and $S$. aureus are shown in Fig. 2 (a-b). Among the three compounds tested, only 2 and 3 had anti-biofilm properties with good activity against $E$. coli, but for $S$. aureus poor inhibition was observed except for only 3 which had activity higher than $50 \%$ at $24 \mathrm{~h}$.

\section{Metabolic activity inhibition}

Results of the metabolic activity inhibition of E. coli and $S$. aureus by the flavonoid compounds are presented in Fig. 3(a-b). Metabolic activity inhibition between 18 and $99 \%$ at $0 \mathrm{~h}$ and $24 \mathrm{~h}$ against $E$. coli and S. aureus was observed with compounds showing weak to good inhibitory activity at both $1 \mathrm{mg} / \mathrm{mL}$ concentration and at MIC levels.

\section{Inhibitory effect of bacterial adhesion to polystyrene surface}

Figure 4(a-b) shows the inhibitory activity of isolated compounds compared to standard antibiotics against $E$. coli and $S$. aureus in a 96-well polystyrene microplate. Although both compounds showed some inhibitory effect, activity was weak against $E$. coli while against $S$. aureus the compounds tended to support bacterial adhesion.

\section{Cytotoxicity screening}

Table 4 shows the result of the cytotoxicity levels of the screened flavonoid compounds against Vero Monkey kidney, Caco2 and C3A cells. None of the isolated compounds was toxic against the cells at the highest concentration $(0.2 \mathrm{mg} / \mathrm{mL})$ tested. Table 5 represent the selectivity index (SI) of the compounds against the bacterial and fungal strains tested. The SI values calculated

Table 3 Antimicrobial activity of isolated flavonoid compounds in $\mathrm{mg} / \mathrm{mL}$

\begin{tabular}{|c|c|c|c|c|c|c|c|c|}
\hline \multirow[t]{2}{*}{ Organism } & \multirow[t]{2}{*}{ Time (h) } & \multicolumn{7}{|c|}{ Compounds } \\
\hline & & 1 & 2 & 3 & 4 & Gent & Cipro & Amp B \\
\hline S. aureus & - & 0.25 & 0.031 & 0.016 & 0.25 & 0.008 & 0.063 & NA \\
\hline E. coli (1) & - & 0.25 & 0.031 & 0.063 & 0.125 & 0.016 & 0.002 & NA \\
\hline E. coli (2) & - & $>0.25$ & 0.031 & 0.25 & $>0.25$ & 0.031 & $5 \times 10^{-5}$ & NA \\
\hline E. coli (3) & - & $>0.25$ & 0.031 & 0.25 & $>0.25$ & 0.008 & $1 \times 10^{-3}$ & NA \\
\hline K. pneumoniae & - & 0.25 & 0.125 & 0.125 & $>0.25$ & 0.25 & 0.05 & NA \\
\hline Mean & - & 0.25 & 0.05 & 0.14 & ND & 0.06 & 0.02 & NA \\
\hline SD & - & 0 & 0.04 & 0.11 & ND & 0.11 & 0.03 & NA \\
\hline \multirow[t]{2}{*}{ C. neoformans } & 48 & $>0.25$ & 0.016 & $>0.25$ & $>0.25$ & NA & NA & 0.08 \\
\hline & 72 & $>0.25$ & 0.125 & $>0.25$ & $>0.25$ & NA & NA & 0.125 \\
\hline \multirow[t]{3}{*}{ A. fumigatus } & 48 & 0.063 & 0.016 & 0.031 & 0.25 & NA & NA & 0.031 \\
\hline & 72 & 0.25 & 0.125 & 0.25 & $>0.25$ & NA & NA & 0.063 \\
\hline & 120 & $>2.5$ & $>2.5$ & $>2.5$ & $>2.5$ & $>2.5$ & NA & NA \\
\hline Mean & & ND & 0.07 & ND & ND & ND & NA & 0.07 \\
\hline SD & & ND & 0.06 & ND & ND & ND & NA & 0.04 \\
\hline
\end{tabular}

E. coli (1): E. coli (ATTC25922) reference strain; E. coli (2): E. coli (B1989/17) isolate; E. coli (3); E. coli (B1962/17) isolate; Gent = gentamicin; Cipro = ciprofloxacin; Amp $B=$ amphotericin $B ; 1=$ compound $1 ; 2=$ compound $2 ; 3=$ compound $3 ; 4=$ compound $4 ; \mathrm{NA}$ : not applicable; ND: not detected; SD: standard deviation. Number in bold indicates good antimicrobial activity 


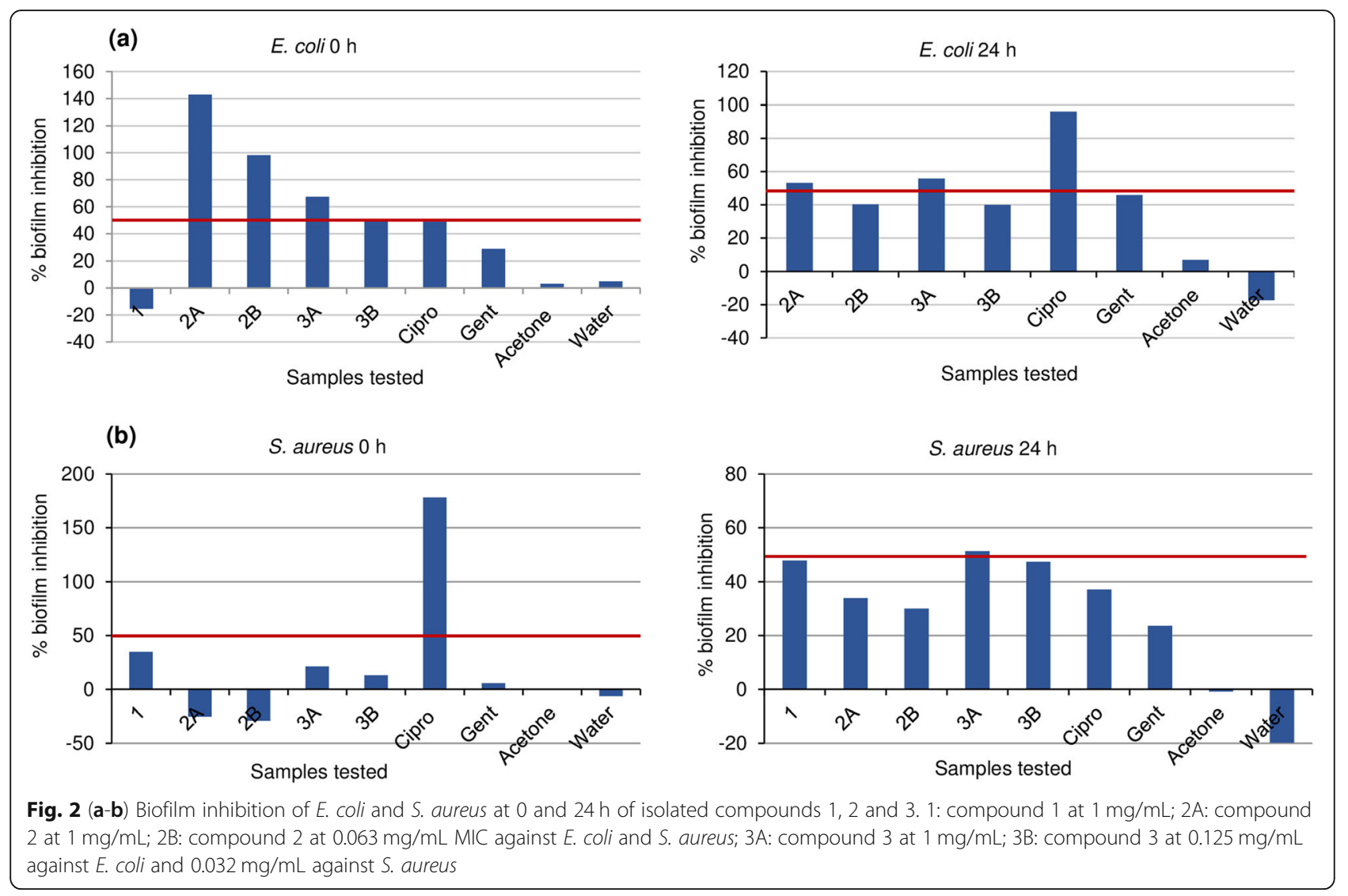

indicate that the antimicrobial, anti-biofilm and metabolic inhibition activities of the compounds were not because of toxicity of the compounds to the microbial strains.

\section{Discussion \\ Isolated compounds}

Five fractions from C. odorata (hexane, chloroform, butanol, ethyl acetate and water) tested against five bacterial and three fungal strains exhibited antimicrobial activity from weak to good activity. However, the hexane and chloroform fractions showed better activity against most of the strains especially E. coli, S. aureus and $K$. pneumoniae which were used for the bio-guided isolation in this study. Most of the sub-fractions collected were more active against $E$. coli, S. aureus, K. pneumoniae, A. fumigatus and C. neoformans (Table 2) which finally resulted in isolation of four compounds with $\mathrm{Rf}$ values of $0.85,0.89,0.91$ and 0.92 respectively. Characterization and structural elucidation of the compounds revealed pectolinaringenin (5,7-dihydroxy-4',6dimethoxy-flavone) (1), ( \pm )-4',5,7-trimethoxy flavanone (2) 3,7,4' -tri-O-methylkaempferol (5-hydroxy-3,7,4' -trimethoxyflavone) (3) and 4'-methoxykaempferol (3,5,7trihydroxy-4' -methoxyflavone) (4).
The presence of the compound 1 in $C$. odorata agrees with that of Wollenweber et al. [57] and Raman et al. [58] who also isolated this compound from the widespread AWAB C. odorata, which has been reported as a very useful medicinal plant in its invasive range. Compound 1 seems to be one of the major flavonoids present in the sunflower Asteraceae family as it has been isolated from other plants of the family which include; Schkuria pinnata (Lam), Buccharis uncinella DC [59]., Cirsium japonicum DC [60]. etc. The compound has also been isolated from other plants belonging to other families, e.g. Plumeria ambigens S. F and Plumeria floribunda L. (Apocynaceae) [61], Clerodendrum phlomidis L.f. (Verbenaceae) [55], Kickxia ramosissima (Wall.) (Plantaginaceae) [62], and Lippia species (Verbenaceae) [63]. The compound has also been obtained through hydrolysis of the rutinose unit of pectolinarin isolated from Linaria reflexa L. (Plantaginaceae) [64]. Compound 2 has been isolated from Launaea arborescens (Batt.) Murb. (Asteraceae) [65]. Compound 3 has also been isolated from Dodonaea viscosa Jacq. var. angustifolia (L.f) Benth. (Sapindaceae). Compound 4 is commercially sold with the name Diosmetin, and is a common compound found in citrus fruits [66]. It has also been isolated from other plant species which include Chrysanthemum morifolium Ramat (Asteraceae) [67], Premna odorata Blanco (Lamiaceae) [68] and Avena fatua L. (Poaceae) [69]. 


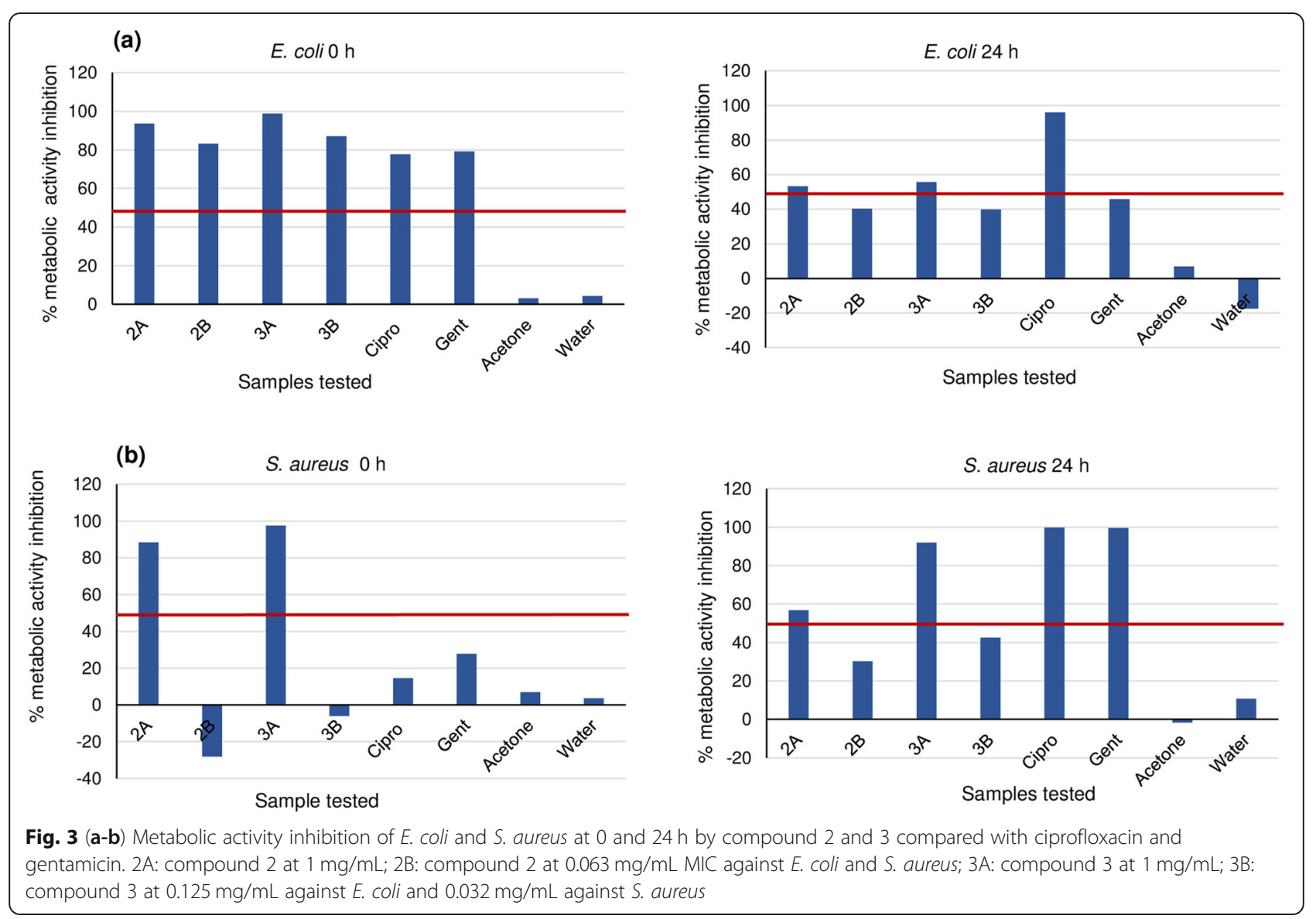

\section{Antimicrobial activity of isolated compounds}

The antimicrobial activity of the isolated compounds from C. odorata against S. aureus, E. coli, K. pneumoniae, A. fumigatus and $C$. neoformans (Table 3 ) showed that the plant is a promising source of antimicrobials, especially the compounds 2 and 3 . The antibacterial activity displayed by these two compounds may be attributed to the presence of the O-methoxy group present at carbon- 4 and carbon-7 located in the $\mathrm{A}$ and $\mathrm{B}$ rings of the two compounds as illustrated in Fig. 1. Better antifungal activity displayed by 2 compared to 3 against $C$. neoformans and $A$. fumigatus may be due to the $\mathrm{O}$ methoxy group located at carbon-5 in the A ring whereas that of 3 is located in carbon- 3 of the $\mathrm{C}$ ring. In a study carried out by Teffo et al. [70] where compound 3 was investigated against $S$. aureus and E. coli, no activity was recorded, contrary to the present finding where MIC values of $0.063 \mathrm{mg} / \mathrm{mL}$ against $E$. coli and 0.016 $\mathrm{mg} / \mathrm{mL}$ against $S$. aureus were observed. However, their findings affirm the result of this study for compound 4 activity against $S$. aureus and $E$. coli where the same MIC values of 0.125 and $0.25 \mathrm{mg} / \mathrm{mL}$ were observed.

Compound 1 showed weak antimicrobial activity in this study except against $A$. fumigatus where good activity was observed at $48 \mathrm{~h}$. The poor activity exhibited may be influenced by the two methoxy rings at carbon- 4 and carbon-6. Derivatives of this compound may be a more effective antimicrobial. The compound has been reported to display antiprotozoal activity against Plasmodium falciparium and Trypanosoma cruzi [62], and antioxidant and anti-inflammatory activities [62, 71]. Other biological activity has been reported on this compound, for example, the compound isolated from a Thai traditional herbal formulation (Benchalokawichian) has been reported to demonstrate anti-allergic activity of the skin [72]. The presence of this compound in C. odorata may explain why the AWAB is said to be effective against skin infections [30, 31, 73]. The compound has demonstrated hepatoprotective activity in a rat model of hepatic injury induced by D-galactosamine [71]. It has also been reported to display antiproliferation activity by inducing apoptosis and deregulation of B-cell lymphoma 2 (Bcl-2) expressions in MCF-7 breast cancer cells [60]. It has shown antitumor activity in mice with $\mathrm{S} 180$ and H22 tumor cells [69]. The compound has also been reported to display larvicidal activity against Aedes aegyptia, Anopheles stephensi and Culex quinquefasciatus and larvicidal pulpicidal and oviposition deterrent activities against Helicoverpa armigera [55, 74, 75]. The compound inhibited constitutive and interleukin-6-induced 
E. coli

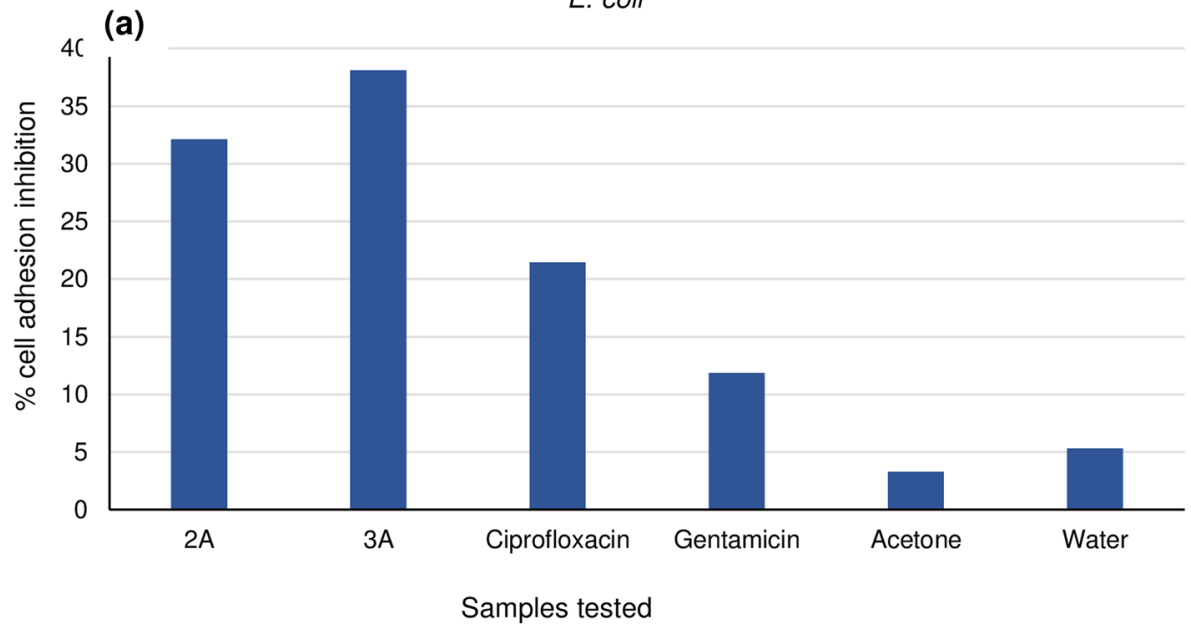

(b)

S. aureus

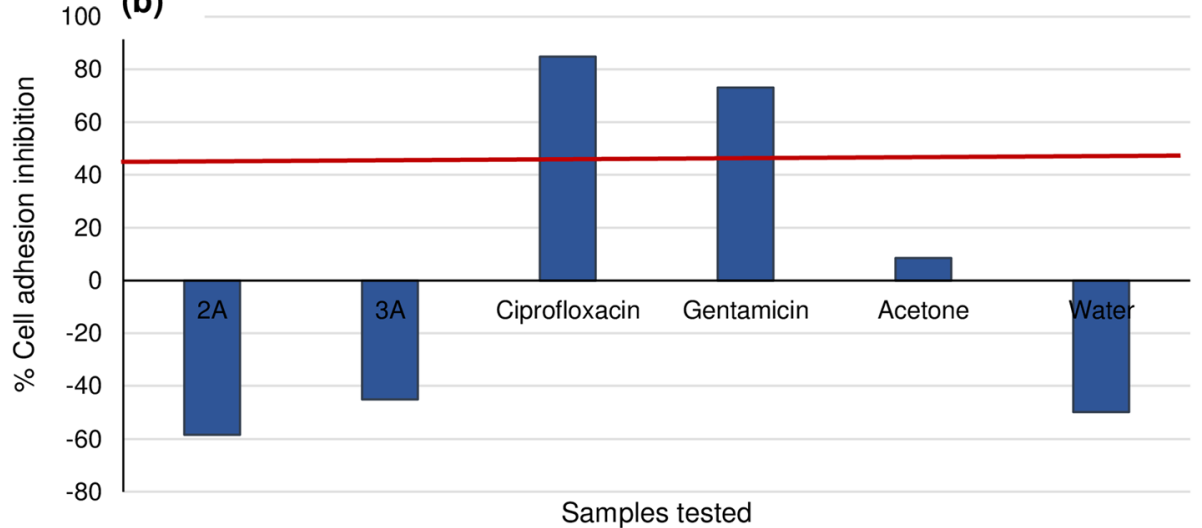

Fig. 4 (a-b). Adherence inhibition of E. coli and S. aureus by isolated compounds 2 and 3 at $1 \mathrm{mg} / \mathrm{mL}$ concentration compared to positive controls

Table 4 Lethal concentration of compounds, and controls tested against Vero monkey kidney, Caco2 and C3A cell lines in $\mathrm{mg} / \mathrm{mL}$

\begin{tabular}{llll}
\hline Sample & Vero cells & Caco2 cells & C3A cells \\
\hline 1 & NA & NA & NA \\
2 & 0.200 & $>0.200$ & $>200$ \\
3 & 0.197 & 0.159 & $>200$ \\
4 & $>0.200$ & 0.193 & NA \\
Ciprofloxacin & $>0.200$ & $>0.200$ & NA \\
Gentamicin & $>0.200$ & $>0.200$ & NA \\
Doxorubicin & $0.0028 \pm 0.012$ & 0.0004 & 0.0033 \\
\hline
\end{tabular}

$1=$ compound $1 ; 2=$ compound $2 ; 3=$ compound $3 ; 4=$ compound $4 ; N A$ not available. $>0.200$ indicates that no sign of toxicity was noticed at the highest concentration tested
STAT3 signaling and diminished the accumulation of STAT3 in the nucleus, blocking STAT3 DNA-binding activity in osteosarcoma cells [76]. This may further explain why AWAB is used in traditional medicine for the treatment of malaria, as a mosquito repellent and as an insecticide [77-81].

Although compound 4 had weak antimicrobial activity against the microorganisms tested, the compound has been reported to be very useful as a nutritional and dietary supplement because of its ability to increase testosterone levels in the blood, assist in the proper functioning of the heart and the circulatory system, lower cholesterol levels in the blood, increase anabolic processes and help in burning fat [82]. It has also been reported to possess good antioxidant activity [70].

\section{Biofilm, metabolic activity and cell adhesion inhibition}

Among the isolated compounds tested, only 2 and 3 showed good inhibitory activity against the planktonic 
Table 5 Selectivity index of microbial strains tested against Vero and Caco2 cell lines

\begin{tabular}{|c|c|c|c|c|c|}
\hline \multirow{2}{*}{$\begin{array}{l}\text { Microbial } \\
\text { strain }\end{array}$} & \multirow[t]{2}{*}{ Cell line } & Time (h) & Compound 2 & \multirow[t]{2}{*}{ Compound 3} & \multirow[t]{2}{*}{ Compound 4} \\
\hline & & \multicolumn{2}{|c|}{ Selectivity index ( $\left.\mathrm{LC}_{50} / \mathrm{MIC}\right)$} & & \\
\hline \multirow[t]{2}{*}{ S. aureus } & Vero & - & 6.516 & 12.313 & $\mathrm{ND}$ \\
\hline & $\mathrm{Caco} 2$ & - & ND & 9.938 & 0.772 \\
\hline \multirow[t]{2}{*}{ E. coli (1) } & Vero & - & 6.515 & 3.127 & ND \\
\hline & $\mathrm{Caco} 2$ & - & ND & 2.52 & 1.544 \\
\hline \multirow[t]{2}{*}{ E. coli (2) } & Vero & - & 6.452 & 0.788 & ND \\
\hline & $\mathrm{Caco} 2$ & - & ND & 0.636 & ND \\
\hline \multirow[t]{2}{*}{ E. coli (3) } & Vero & - & 6.452 & 0.788 & ND \\
\hline & $\mathrm{Caco} 2$ & - & ND & 0.636 & ND \\
\hline \multirow[t]{2}{*}{ K. pneumoniae } & Vero & - & 1.616 & 1.576 & ND \\
\hline & $\mathrm{Caco} 2$ & - & ND & 1.272 & NA \\
\hline \multirow[t]{4}{*}{ C. neoformans } & Vero & 48 & 12.625 & NA & ND \\
\hline & & 72 & 1.616 & NA & ND \\
\hline & $\mathrm{Caco} 2$ & 48 & ND & NA & NA \\
\hline & & 72 & ND & NA & NA \\
\hline \multirow[t]{4}{*}{ A. fumigatus } & Vero & 48 & 12.625 & 6.355 & ND \\
\hline & & 72 & 1.616 & 0.788 & ND \\
\hline & $\mathrm{Caco} 2$ & 48 & ND & 5.129 & 0.7772 \\
\hline & & 72 & ND & 0.636 & NA \\
\hline
\end{tabular}

$N D$ not detected due to $\mathrm{LC}_{50}$ greater than the highest concentration of $0.2 \mathrm{mg} / \mathrm{mL}$ tested showing no toxicity, $N A$ not available as a result of the sample not being able to inhibit the tested fungal strain at highest concentration

and mature biofilms of $E$. coli and the mature biofilm of $S$. aureus even at the MIC levels tested (Fig. 2a-b). This indicates that these compounds have preventive ability against infection caused by these organisms and may also serve as effective treatment. The same trend was observed with the compounds 2 and 3 against the metabolic activity of $E$. coli and $S$. aureus both at the planktonic and biofilm stages (Fig. 3a-b), except for $S$. aureus where only the MIC of $0.063 \mathrm{mg} / \mathrm{mL}$ did not show inhibition at the planktonic stage. The ability of these compounds to inhibit the metabolic activity of the bacterial strains implies that these compounds may have the ability to distort the metabolic activity of the organisms, although a further study is recommended to establish this. In comparing activity displayed between the Gram-positive and Gram-negative strains, better antibiofilm activity was observed by the compounds against E. coli. The trend of anti-biofilm and metabolic inhibitory activities exhibited by these compounds against $E$. coli and S. aureus in this study agrees with that of Mohsenipour and Hassanshahian [83] where they tested Thymus vulgaris L. (Lamiaceae) extracts against both strains.

Anti-adherence activity displayed by the compounds against $E$. coli was weak, while for $S$. aureus the isolated compounds promoted bacterial adhesion to the protein BSA on the polystyrene surface. It may not be impossible that the poor anti-adhesion obserevd in this study may be due to the method used, hence, further studies is suggested. Athough good anti-adhehence activity was not noticed with this plant in this study, some other plants of the Asteraceae family have been reported to have good anti-adherence activity [84].

\section{Safety evaluation through cytotoxicity}

The cytotoxicity screening of the flavonoid compounds showed that none of the compounds or positive controls was toxic against Vero monkey kidney, Caco2 or C3A human cells at the highest concentration tested. This implies that the pharmacological activity displayed against the bacterial and fungal strains was not because of toxicity. Selectivity index values between 1 and 12 for all compounds tested indicate that the compounds were more toxic to the bacterial and fungal strains than the cells investigated. This implies that the isolated compounds may be useful in the treatment of UTIs caused by the investigated strains, without much fear of safety $[8,85,86]$. However, in vivo studies will be relevant with regards to this.

\section{Conclusions}

The global health challenges caused by UTIs resulting from microbial infections cannot be overlooked, as they are among the major contributors to high morbidity and mortality, especially in immuno-compromised individuals. 
Following a biological assay-guided isolation, four compounds were isolated from the SAB biotype of $C$. odorata. Amongst the four compounds isolated from the alien invasive plant, only two compounds, ( \pm )-4',5,7-trimethoxy flavanone and 5-hydroxy-3,7,4' -trimethoxyflavone showed promising antimicrobial activity against E. coli, S. aureus, K. pneumoniae, A. fumigatus and C. neoformans, which are implicated as some of the major pathogens causing UTIs. The results from this study show that the investigated flavonoid compounds may be useful in the fight against UTIs. The compounds also showed promising anti-biofilm activity against $E$. coli and $S$. aureus. This supports their potential development into useful prophylactic treatments and as anti-infective drugs. Also, their ability to inhibit the metabolic activity of the bacterial strains implies that these compounds may have the ability to distort the metabolic activity of the organisms, although a further study is recommended to establish this. This is the first time these compounds have been isolated from this biotype of $C$. odorata. This study is the first to investigate the antimicrobial, anti-biofilm, metabolic activity and cell adhesion inhibition potentials of the isolated compounds from the SAB C. odorata. A further study to evaluate the compounds as possible adjuvant treatments with conventional antibiotics will be appropriate.

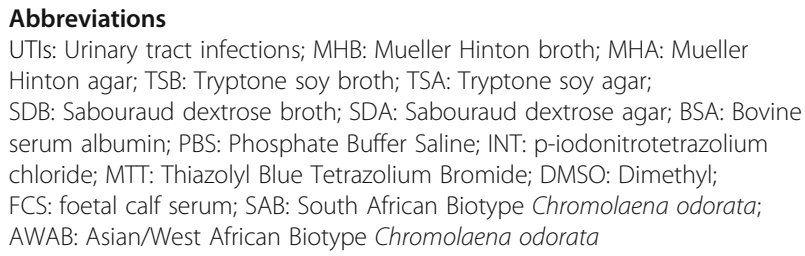

\section{Acknowledgements}

AG Omokhua-Uyi is grateful to the National Research Foundation-The World Academy of Science (NRF-TWAS) for providing funding.

\section{Declaration}

The authors of this manuscript hereby declare that the results from this manuscript were obtained from the experiments carried out by them, that each author contributed, that the results from these findings have not been published in any other journal, and that all literature consulted have been duly acknowledged at the reference section.

\section{Authors' contributions}

AGO-U and LM conceptualized the research. AGO-U conducted the experiments with assistance from AOA, CML and MAA, MAA assisted with the structural elucidation and identification, $\mathrm{OOU}$ assisted with the plant material collection, voucher specimen preparation and statistical analysis. AGO-U and OOU wrote the first draft of the manuscript, CML, MAA, JVS and LJM supervised the work. All authors revised the final manuscript and all authors read and approved the final manuscript.

\section{Funding}

The National Research Foundation, South Africa provided research funding to LJM (Grant Number 105993). The funding body had no role in the design of the study or interpretation of the results.

\section{Availability of data and materials}

Dataset and materials can be made available upon reasonable request from the senior author.
Ethics approval and consent to participate

No experiments on humans or animals were carried out hence no ethics approval was required.

\section{Consent for publication \\ Not applicable.}

\section{Competing interests}

The authors of this manuscript declare no competing interest.

\section{Author details}

'Phytomedicine Programme, Department of Paraclinical Sciences, University of Pretoria, Private Bag X04, Onderstepoort 0110, South Africa. ${ }^{2}$ Research Centre for Plant Growth and Development, School of Life Sciences, University of KwaZulu-Natal, Private Bag X01, Scottsville 3201, South Africa. ${ }^{3}$ Deparment of Food Science and Technology, Faculty of Agriculture, University of Khartoum, 13314 Khartoum North, Sudan. ${ }^{4}$ Department of Pharmaceutical Sciences, Tshwane University of Technology, Private Bag X680, Pretoria 0001, South Africa. ${ }^{5}$ Department of Animal and Environmental Biology, University of Benin, P.M.B, Benin City 1154, Nigeria.

Received: 7 August 2019 Accepted: 10 July 2020

Published online: 23 July 2020

\section{References}

1. Centers for Disease Control and Prevention (CDC). CDC, treating opportunistic infections among HIV-Infected adults and adolescents. Recommend Rep. 2004;53:1-112.

2. Bhatti Z, Shaukat A, Almyroudis N, Segal B. Review of epidemiology, diagnosis, and treatment of invasive mould infections in allogeneic hematopoietic stem cell transplant recipients. Mycopathologia. 2006;162:1-15.

3. Sellner J, Tauber MG, Leib SL. Pathogenesis and pathophysiology of bacterial CNS infections. Handbook Clin Neuro. 2010;96:1-16.

4. Stamm WE, Norrby SR. Urinary tract infections: Disease panorama and challenges. J Infect Dis. 2001;183:1-4.

5. Bonacini M, Nussbaum J, Ahluwalia C. Gastrointestinal, hepatic and pancreatic involvement with Cryptococcus neoformans in AIDS. J Clin Gastroenterol. 1990;12:295-7.

6. Washington K, Gottfried MR, Wilson ML. Gastrointestinal cryptococcosis. Mod Pathol. 1991:4:707-11.

7. Kiertiburanakul S, Sungkanuparph S, Buabut B, Pracharktam R. Cryptococcuria as a manifestation of disseminated cryptococcosis and isolated urinary tract infection. Jap J Infect Dis. 2004:57:203-5.

8. Farajnia S, Alikhani MY, Ghotaslou R, Naghili B, Nakhlband A. Causative agents and antimicrobial susceptibilities of urinary tract infections in the northwest of Iran. Inter J Infect Dis. 2009;13:140-4.

9. Mittal R, Aggarwal S, Sharma S, Chhibber S, Harjai K. Urinary tract infections caused by Pseudomonas aeruginosa: a minireview. J Infect Publ Health. 2009;2:101-11.

10. Schappert SM, Rechtsteiner EA. Ambulatory medical care utilization estimates for 2007. Vit Health Stat. 2011;13:1-38.

11. Rampure R, Gangane R, Oli AK. Prevalence of MDR-ESBL producing Klebsiella pneumoniae isolated from clinical samples. J Microb Biotech Res. 2013;3:32-9.

12. Tachjian A, Maria V, Jahangir A. Use of herbal products and potential interactions in patients with cardiovascular diseases. J Am Coll Cardiol. 2010; 55:515-25.

13. Sasidharan $S$, Chen Y, Saravanan D, Sundram KM, Latha LY. Extraction, isolation and characterization of bioactive compounds from plants' extracts. Afr J Tradit Complement Altern Med. 2011;8:1-10.

14. Davies D. Understanding biofilm resistance to antibacterial agents. Nat Rev Drug Discov. 2003;2(2):114-22.

15. Lenz AP, Williamson KS, Pitts B, Stewart PS, Franklin MJ. Localized gene expression in Pseudomonas aeruginosa biofilms. Appl Environ Microbiol. 2008;74(14):4463-71.

16. Zhang L, Mah TF. Involvement of a novel efflux system in biofilm-specific resistance to antibiotics. J Bacteriol. 2008;190(13):4447-52.

17. Barraud N, Schleheck D, Klebensberger J, Webb JS, Hassett DJ, Rice SA, Kjelleberg S. Nitric oxide signaling in Pseudomonas aeruginosa biofilms mediates phosphodiesterase activity, decreased cyclic di-GMP levels, and enhanced dispersal. J Bacteriol. 2009;191(23):7333-42. 
18. Donlan RM. Biofilm formation: a clinically relevant microbiological process. Clin Infect Dis. 2001;33(8):1387-92.

19. Duraipandiyan V, Ayyanar M, Ignacimthu S. Antimicrobial activity of some ethnomedicinal plants used by Paliyar tribe from Tamil Nadu, India. BMC Complement Altern Med. 2006;6:1-7.

20. Kriticos DJ, Yonow T, McFadyen RE. The potential distribution of Chromolaena odorata (Siam weed) in relation to climate. Weed Res. 2005;45:246-54.

21. Ivens GW. The problem of Eupatorium odoratum L. in Nigeria. Pest Articl News Summ. 1974;20:76-82.

22. Zachariades C, Strathie LW, Retief E, Dube N. Progress towards the biological control of Chromolaena odorata (L.) R.M. king and H. rob. (Asteraceae) in South Africa. Afr Entomol. 2011;19:282-302.

23. Uyi OO, Ekhator F, Ikuenobe CE, Borokini TI, Aigbokhan El, Egbon IN, Adebayo AR, Igbinosa IB, Okeke CO, Igbinosa EO, Omokhua AG. Chromolaena aodorata invasion in Nigeria: a case for coordinated biological control. Mgt Bio Invas. 2014;5:377-93.

24. Zachariades C, Day M, Muniappan R, Reddy GVB. Chromolaena odorata (L.) King and Robinson (Asteraceae). In: Muniappan R, editor. Biological Control of Tropical Weeds using Arthropods. Cambridge: Cambridge University Press; 2009. p. 130

25. Paterson ID, Zachariades C. ISSRs indicate that Chromolaena odorata invading southern Africa originates in Jamaica or Cuba. Biol Control. 2013;66:132-9.

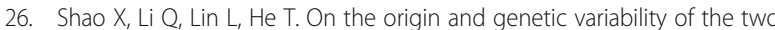
invasive biotypes of Chromolaena odorata. Bio Invas. 2018;20(8):2033-46.

27. Timbilla JA, Zachariades C, Braimah H. Biological control and management of the alien invasive shrub Chromolaena odorata in Africa. In: Neuenschwander P, Borgemeister C, Langewald J, editors. Biological control in IPM Systems in Africa. Wallingford: CABI Publishing; 2003.

28. Uyi OO, Igbinosa IB. The status of Chromolaena odorata and its biocontrol in West Africa. In: Zachariades C, Strathie LW, Day MD, Muniappan R, editors. Proceedings of the eighth international workshop on biological control and Management of Chromolaena odorata and other Eupatorieae, Nairobi, Kenya, 1-2. November 2010. Pretoria: ARC-PPRl; 2013. p. 86-98.

29. Adjanohoun E, Ake-Assi L. Contributionau Recensementdes Plantes Médicinale de Côted'Ivoire. Abidjan: Centre National de Floristique; 1979.

30. Inya-Agha SI, Oguntimein BO, Sofowora A, Benjamin TV. Phytochemical and antibacterial studies on the essential oil of Eupatorium odoratum. Inter J Crude Drug Res. 1987;25:49-52.

31. Bamba D, Bessiere JM, Marion C, Pelissier Y, Fouraste I. Essential oil of Eupatorium odoratum. Planta Med. 1993:59:184-5.

32. Ayensu ES. Medicinal plant of West Africa. Algonac Michigan: Reference Publications Inc; 1978.

33. Thakong K. A study on the antimalarial constituents and chemical composition of Eupatorium odoratum L. Msc. Thesis: Mahidol University Bangkok; 1999.

34. Bédi G, Tonzibo ZF, Chopard C, Mahy JP, N'Guessan TY. Etude des effets anti douleurs des huiles essentielles de Chromolaena odorata et de Mikania Cordata, par action sur la lipoxygenase. Phys Chem News. 2004;15:124-7.

35. Amatya S, Tuladhar SM. In vitro antioxidant activity of extracts from Eupatorium odoratum L. Res J Med Plants. 2011;5:79-84.

36. Bhargava D, Sanjay K, Jagadish NS, Bicash S, Chiranjit MS. Screening of antigonorrhoeal activity of some medicinal plants in Nepal. Inter Pharm Bio Sci. 2011;2:203-12

37. Omokhua AG, McGaw LJ, Finnie JF, Van Staden J. Chromolaena odorata (L.) R.M. King \& H. rob. (Asteraceae) in sub Saharan Africa: a synthesis and review of its medicinal potential. J Ethnopharmacol. 2016;183:112-22.

38. Omokhua AG, McGaw LJ, Chukwujekwu JC, Finnie JF, Van Staden J. A comparison of the antimicrobial activity and in vitro toxicity of a medicinally useful biotype of invasive Chromolaena odorata (Asteraceae) with another biotype not used in traditional medicine. SAJB. 2017;108:200-8.

39. Omokhua AG, Madikizela B, Aro A, Uyi OO, Van Staden J, McGaw LJ. Noxious to ecosystems, but relevant to pharmacology: four south African alien invasive plants with pharmacological potential. SAJB. 2018;117:41-9.

40. Atanasov AG, Waltenberger B, Pferschy-Wenzig EM, Linder T, Wawrosch C, Uhrin P, Temml V, Wang L, Schwaiger S, Heiss EH, Rollinger JM, Schuster D, Breuss JM, Bochkov V, Mihovilovic MD, Kopp B, Bauer R, Dirsch VM, Stuppner H. Discovery and resupply of pharmacologically active plantderived natural products: a review. Biotech Adva. 2015;33:1582-614.

41. Cos P, Vlietinck AJ, Vanden Berghe D, Maes L. Anti-infective potential of natural products, how to develop a stronger in vitro "proof-of concept". J Ethnopharmacol. 2006;106:290-302.
42. McGaw LJ, Eloff JN. Methods for evaluating efficacy of ethnoveterinary medicinal plants. Ethnoveterinary Botanical Medicine: Herb Med Anima Health; 2010. p. 1-24.

43. Suffness M, Douros J. Drugs of plant origin. Meth Cancer Res. 1979;26:73-126.

44. Eloff JN. Which extractant should be used for the screening and isolation of antimicrobial components from plants? J Ethnopharmacol. 1998;60:1-8.

45. Elisha IL, Jambalang AR, Botha FS, Buys EM, McGaw LJ, Eloff JN. Potency and selectivity indices of acetone leaf extracts of nine selected south African trees against six opportunistic Enterobacteriaceae isolates from commercial chicken eggs. BMC Complement Altern Med. 2017;17(90):1-8.

46. Eloff JN. A sensitive and quick microplate method to determine the minimal inhibitory concentration of plant extracts for bacteria. Planta Med. 1998:64:711-4.

47. Sandasi M, Leonard CM, Van Vuuren SF, Viljoen AM. Peppermint (Mentha piperita) inhibits microbial biofilms in vitro. SAJB. 2011;77:80-5.

48. Ramage G, Lopez-Ribot JL. Techniques for antifungal susceptibility testing of Candida albicans biofilms. Meth Mol Med. 2005;118:71-9.

49. Namasivayam SKR, Vivek JM. Anti-quorum sensing activities of medicinal plant extracts against quorum sensing mediated virulence factors of Pseudomonas aeruginosa. Pharm Lett. 2016;8:412-23.

50. Mosmann T. Rapid colorimetric assay for cellular growth and survival: application to proliferation and cytotoxicity assays. J Immunol Meth. 1983; 65:55-63.

51. McGaw LJ, Steenkamp V, Eloff JN. Evaluation of Athrixia bush tea for cytotoxicity, antioxidant activity, caffeine content and presence of pyrrolizidine alkaloids. J Ethnopharmacol. 2007;110:16-22.

52. Mabry TJ, Harborne JB. The flavonoids: advances in research. London; New York: Chapman and Hall; 1982.

53. Leitao GG, Soares SSV, De Barros T, Brito M, Monache FD. Kaempferol glycosides from Siparuma apiosyce. Phytochemistry. 2000;55:679-82.

54. Rajkapoor B, Murugesh N, Krishna DR. Cytotoxic activity of a flavanone from the stem of Bauhinia variegata Linn. Nat Prod Res. 2010;23:1384-9.

55. Duraipandiyan V, Muthu C, Baskar K, Al-Dhabi NA, Ignacimuthu S. Evaluation of fractions and 5,7-dihydroxy-4,6-dimethoxy-flavone from Clerodendrum phlomidis Linn. F. against Helicoverpa armigera hub. Braz Arch Bio Tech. 2015;58:154-65.

56. Nantapap S, Punyanitya S, Nuntasaen N, Pompimon W, Meepowpan P. Flavones from aerial parts of Polyalthia bullata and cytotoxicity against cancer cell lines. Chem Nat Compd. 2017;53:762-763.

57. Wollenweber E, Dorr M, Muniappan R. Exudate flavonoids in a tropical weed, Chromolaena odorata. Biochem Syst Ecol. 1995;23:873-4.

58. Raman VB, Samuel LA, Saradhi PM, Rao NB, Vamsi Krishna NA, Sudhakar M, Radhakrishnan TM. Antibacterial, antioxidant activity and GC-MS analysis of Eupatorium odoratum. Asian J Pharmacol Clin Res. 2012;5:99-106.

59. Zalewski CA, Passero LFD, Melo ASRB, Corbett CEP, Laurenti MD, Toyama $\mathrm{MH}$, Toyama DO, Romoff P, Fávero OA, Lago JHG. Anti-inflammatory activity of derivatives from aerial parts of Baccharis uncinella DC. (Asteraceae). Pharm Bio. 2011:49:602-7.

60. Lu M, Kong Q, Xu X, Lu H, Lu Z, Yu W, Zuo B, Su J, Guo R. Pectolinarigenin a flavonoid compound from Cirsium japonicum with potential antiproliferation activity in MCF7 breast cancer cell. Trop J Pharm Res. 2014;13: 225-8.

61. Bierner MW. Flavonoids of Plummera: taxonomic implications at the generic level within the Gaillardiinnae. Biochem Syst Ecol. 1978;6:293-5.

62. Amin A, Tuenter E, Foubert K, labal J, Cos P, Maes L, Exarchou V, Apers S, Pieters L. In vitro and In silico antidiabetic and antimicrobial evaluation of constituents from Kickxia ramosissima (Nanorrhinum ramosissimum). Front Pharmacol. 2017;8:232.

63. Trevisan MTS, Marques RA, Silva MGV, Scherer D, Haubner R, Ulrich CM, Owen RW. Composition of essential oils and ethanol extracts of the leaves of Lippia species: identification, quantitation and antioxidant capacity. Rec Nat Prod. 2016;10:485-96.

64. Bonesi M, Tundis R, Deguin B, Loizzo MR, Menichini F, Tillequin F, Menichini F. In vitro biological evaluation of novel 7-O-dialkylaminoalkyl cytotoxic pectolinarigenin derivatives against a panel of human cancer cell lines. Bioorg Med Chem Lett. 2008;18:5431-4.

65. Sekkoum K, Belboukhari N, Cheriti A. New flavonoids from bioactive extract of Algerian medicinal plant Launeae arborescens. Asian Pac J Trop Biomed. 2014;4:267-71.

66. Michael HN, Salib JY, Eskander EF. Bioactivity of diosmetin glycosides isolated from the epicarp of date fruits, Phoenix dactylifera, on the 
biochemical profile of alloxan diabetic male rats. Phytother Res. 2013;27: 699-704.

67. Lee S, Jung T, Kim H, Jeong D, Choi G, Park W, Kong JY, Jin M, Cho H. Inhibition of c-kit signaling by diosmetin isolated from Chrysanthemum morifolium. Arch Pharm Res. 2014;37:175-85.

68. Pinzon LC, Uy MM, Sze KH, Wang M, Chu IK. Isolation and characterization of antimicrobial, anti-inflammatory and chemopreventive flavones from Premna odorata Blanco. J Med Plants Res. 2011;5:2729-35.

69. Liu X, Tian F, Tian Y, Wu Y, Dong F, Xu J, Zheng Y. Isolation and identification of potential allelochemicals from aerial parts of Avena fatua $\mathrm{L}$. and their allelopathic effect on wheat. J Agric Food Chem. 2016;64:3492-500.

70. Teffo LS, Aderogba MA, Eloff JN. Antibacterial and antioxidant activities of four kaempferol methyl ethers isolated from Dodonaea viscosa Jacq var angustifolia leaf extracts SAJB 2010;76:25-29.

71. Yoo YM, Nam JH, Kim MY, Choi J, Park HJ. Pectolinarin and pectolinarigenin of Cirsium setidens prevent the hepatic injury in rats caused by D-galactosamine via an antioxidant mechanism. Bio Pharm Bull. 2008;31:760-4.

72. Juckmeta T, Thongdeeying P, Itharat A. Inhibitory effect on Hexosaminidase release from RBL-2H3 cells of extracts and some pure constituents of Benchalokawichian, a Thai herbal remedy, used for allergic disorders. Evid Based Complement Alternat Med. 2014;8.

73. Owoyele VB, Adediji JO, Soladoye AO. Anti-inflammatory activity of aqueous leaf extract of Chromolaena odorata. Inflammopharmacol. 2005;13:479-84.

74. Muthu C, Baskar K, Ignacimuthu S, Al-Khaliel AS. Ovicidal and oviposition deterrent activities of the flavonoid pectolinaringenin from Clerodendrum phlomidis against Earias vittella. Phytoparasitica. 2013:41:365-72.

75. Muthu C, Baskar K, Ignacimuthu S, Duraipandiyan V, Al-Dhabi NA. Bioefficacy of pectolinaringenin from Clerodendrum phlomidis Linn. F. against Anopheles stephensi and bhendi fruit borer, Earias vittella fab. Braz Arch Bio Tech. 2015; 58:358-66.

76. Zhang T, Li S, Li J, Yin F, Hua Y, Wang Z, Lin B, Wang H, Zou D, Zhou Z, Xu $J, Y i C$, Cai Z. Natural product pectolinarigenin inhibits osteosarcoma growth and metastasis via SHP-1-mediated STAT3 signaling inhibition. Cell Death Dis. 2016;7:e2421.

77. Uyi OO, Adetimehin AD, Ogu PO. Repellent and insecticidal activities of the root extracts of Chromolaena odorata and Mimosa diplotricha against Macrotermes species. J Entomol. 2018;15(3):135-42.

78. Uyi OO, Adetimehin AD. Efficacy of the stem powder of an invasive alien plant, Chromolaena odorata (L) (Asteraceae) against Callosobruchus maculatus (Fab.) (Coleoptera: Chrysomelidae). J Appl Sci Enviro Mgt. 2018; 22(3):379-85.

79. Adetimehin AD, Ejomah AJ, Uyi OO. Efficacy of Chromolaena odorata (L.) (Asteraceae) root powder against the tropical bedbug, Cimex hemipterus (F.) (Hemiptera: Cimicidae) Asian J. Biol Sci. 2019;12(4):905-10.

80. Uyi OO, Obi BN. Evaluation of the repellent and insecticidal activities of the leaf, stem and root powders of Siam weed (Chromolaena odorata) against the cowpea beetle, Callosobruchus maculatus. J Appl Sci Enviro Mgt. 2017; 21:511-8.

81. Youmsi RDF, Fokou P, Menkem EZ, Bakarnga-Via I, Keumoe R, Nana V, Boyom FF. Ethnobotanical survey of medicinal plants used as insects' repellents in six malaria endemic localities of Cameroon. J Ethnobiol Ethnomed. 2017;13:33.

82. Muscle zone (Mz). 3',5,7-Trihydroxy-4'-Methoxyflavone Subs4You LCC, USA, 2018.

83. Mohsenipour Z, Hassanshahian M. The inhibitory effect of Thymus vulgaris on the planktonic form and biofilm structures of six human pathogenic bacteria. Avicena J Phytomed. 2015:5:309-18.

84. Yatsuda R, Rosalen PL, Cury JA, Murata RM, Rehder VL, Melo LV, Koo H. Effects of Mikania genus plants on growth and cell adherence of mutans streptococci. J Ethnopharmacol. 2005;97(2):183-9.

85. Gaynes R, Edwards JR. Overview of nosocomial infections caused by gramnegative bacilli. Clin Infect Dis. 2005;41:848-54.

86. Kariuki S, Revathi G, Corkill J, Kiiru J, Mwituria J, Mirza N, Hart CA. Escherichia coli from community-acquired urinary tract infections resistant to fluoroquinolones and extended-spectrum beta-lactams. JIDC. 2007;1:257-62.

\section{Publisher's Note}

Springer Nature remains neutral with regard to jurisdictional claims in published maps and institutional affiliations.

Ready to submit your research? Choose BMC and benefit from:

- fast, convenient online submission

- thorough peer review by experienced researchers in your field

- rapid publication on acceptance

- support for research data, including large and complex data types

- gold Open Access which fosters wider collaboration and increased citations

- maximum visibility for your research: over $100 \mathrm{M}$ website views per year

At BMC, research is always in progress.

Learn more biomedcentral.com/submissions 